\title{
THE EFFECT OF N-STEAROYLETHANOLAMINE ON CHOLESTEROL CONTENT, FATTY ACID COMPOSITION AND PROTEIN CARBONYLATION LEVEL IN RATS WITH ALIMENTARY OBESITY-INDUCED INSULIN RESISTANCE
}

\author{
O. V. ONOPCHENKO, G. V. KOSIAKOVA, E. F. MEGED, \\ V. M. KLIMASHEVSKY, N. M. HULA \\ Palladin Institute of Biochemistry, National Academy of Sciences of Ukraine, Kyiv; \\ e-mail: onop.89.av@mail.ru
}

\begin{abstract}
The effect of $N$-stearoylethanolamine (NSE) on liver free fatty acid composition, cholesterol content and carbonylated protein level in rats with obesity-induced insulin resistance (IR) was studied in the work. The experimental insulin resistance was induced by prolonged high fat diet (58\% of energy derived from fat) for 6 months combined with one injection of low-dose $(15 \mathrm{mg} / \mathrm{kg})$ of streptozotocin. The lipid assay showed a rise in liver free cholesterol content and a significant reduction in cholesterol esters level. Analyzing liver fatty acid composition, a decrease in polyunsaturated of fatty acid (PUFA) level and an increase in monounsaturated fatty acid (MUFA) content was found. Fatty acid imbalance with high content of MUFA was associated with elevated level of protein carbonylation. The NSE administration (50 mg/kg of body weight) for 2 weeks decreased free cholesterol content, increased cholesterol esters level and reduced free oleic fatty acid content in the liver of rats with IR. The effect of NSE on lipid imbalance led to a decrease in protein carbonylation level that may result in improvement of transmembrane protein function under obesity-induced insulin resistance state.
\end{abstract}

Ke y words: $N$-stearoylethanolamine, cholesterol content, free fatty acid composition, protein carbonylation, liver, obesity, experimental insulin resistance.

$\mathrm{N}$ owadays obesity has achieved a status of a pandemic disease, which is associated with a variety of metabolic disorders, such as dyslipidemia, insulin resistance, oxidative stress and inflammation. These are the main factors that cause the development of type 2 diabetes. Chronic high fat diet hypernutrition, rich in saturated fatty acids, stimulate intracellular pathways, leading to oxidative stress through multiple biochemical mechanisms, such as superoxide generation from NADPH oxidases, oxidative phosphorylation, glyceraldehyde autoxidation, activation of polyol and hexosamine pathways [1]. Fat accumulation increases NADPH oxidases' activity, thus triggering the development of oxidative stress in adipocytes that lead to increased reactive oxygen species (ROS) production [2]. Recently, it was shown that the high fat diet-induced obesity also correlates with mitochondrial dysfunction and increased oxidative stress in the liver [3]. The generated ROS directly interact with proteins or may react with carbohydrates and lipids thus, producing the reactive carbonyl species, which can subsequently interact with proteins [4]. Irreversible protein carbonylation results not only in enzyme inactivation but also in initiation of several signaling pathways, launching a cascade of NF-kB activation that leads to the development of IR [5]. An increase in protein oxidation is associated with dyslipidemia [6]. The systemic and cellular dyslipidemia is postulated to play a critical role in the development of diet-induced insulin resistance [7].

Recently discovered compounds $\mathrm{N}$-acylethanolamines (NAE) belong to endocannabinoid system and play an important role in adaptation process, modulating neuroendocrine and behavioral responses to stress, pro-/antioxidant balance and lipid metabolism in different tissues under different pathologies. Until now, all research was focused on the investigation of unsaturated NAEs, primarily anandamid (N-arachidonoylethanolamine). Nevertheless, it was shown that one of the biggest disadvantages of anandamid application was its addiction. The biological effects of saturated N-stearoylethanolamine (NSE) are not widely studied; however, it is known 
that saturated NAE are at relatively high levels under pathological conditions compared to other NAEs that may be due to their leading role in corrective processes. Earlier our research group has shown the membrane stabilizing and protective effect of NSE, affecting saturated/unsaturated fatty acids ratio and cholesterol content [8, 9]. In addition, in previous work the anti-oxidative effect of NSE via the decrease of lipid peroxidation products and activation of antioxidant enzymes in the rat liver with high fat diet (HFD)-induced insulin resistance was found [10].

Taking into account the role of dyslipidemia in enhancing protein peroxidation level and its relation to the insulin signaling impairment, the aim of our research was to study the influence of NSE on the lipid profile (cholesterol contents, fatty acid composition) and the level of protein peroxidation products in the liver of rats with HFD-induced IR.

\section{Materials and Methods}

Animal model. The experiment was conducted with Sprague-Dawley male rats (200-220 g), and performed in accordance with the institution's guide for the care and use of laboratory animals. The animals were housed in standard cages with free access to food and water.

The experimental IR was induced in rats by prolonged HFD ( $58 \%$ fat : $23 \%$ proteins : $10 \%$ carbohydrates) for 6 months combined with one low-dose injection of streptozotocin ( $15 \mathrm{mg} / \mathrm{kg}$ of body weight) at the end of the experiment to cause initial $\beta$-cell dysfunction, that was described in our previous work [10]. The amount of lipids was increased by adding some lard with a high level of palmitic (24\% of total fatty acids) and stearic (28\% of total acids) acids to the normal diet. Interesting to submit that cholesterol content of lard was not at a high level $(0.57 \mathrm{mg} / \mathrm{g}$ of lard). The assay of HFD fatty acid composition showed the ratio of saturated/unsaturated fatty acid $55 / 45$ (\%) respectively. Control rats during the experiment were on normal pellet diet (4\% fat : $23 \%$ proteins : $65 \%$ carbohydrates) with saturated/unsaturated fatty acid ratio - 38/62 (\%). Throughout HFD the rats were gradually gaining the weight and on the 24 week of the experiment the average weight was 400-420 g in comparison with control rats of 330-350 g.

Two weeks after the streptozotocin (STZ) injection, the oral glucose tolerance test was conducted [10]. According to the results, the rats with impaired glucose tolerance (the level of blood glucose within 150 min after the oral glucose administration was higher than $5 \mathrm{mM}$ ) were selected and divided into 2 groups: "IR" $(n=9)$ and "IR+NSE" $(n=10)$. The water suspension of NSE was orally administrated at a dose of $50 \mathrm{mg} \cdot \mathrm{kg}^{-1}$ of body weight for 2 weeks to the rats from "IR+NSE" group. The control rats were divided into the group of "Control" and the group of "NSE" rats; the water suspension of NSE was orally administrated $\left(50 \mathrm{mg} \cdot \mathrm{kg}^{-1}\right.$ of body weight) for 2 weeks to the animals from "NSE" group. This particular NSE dose has been chosen as the optimal reacting dose for biological effect investigations. Schmid H. H. et al. discovered earlier the exact concentration of NSE during the experiment of dog coronary artery occlusion [11].

The confirmation of the IR existence was based on the results of glucose and insulin plasma content assays that are provided below in Fig. 1 .

At the end of the experimental period, the rats were decapitated under Nembutal anesthesia. The liver was immediately taken and frozen at $-80^{\circ} \mathrm{C}$ until analysis.

The liver tissue was homogenized in physiological saline solution, $0.5 \mathrm{ml}$ of $10 \%$ homogenate was taken for protein oxidation products investigation and the rest of it was taken for lipid content assay.

Protein carbonylation. The liver levels of oxidized proteins were measured using 2,4-dinitrophenylhydrazine (DNPH) [12, 13]. A sample (1-1.5 mg protein/ml) was divided into two 1-ml portions, a "Test" and a "Blank". The samples were precipitated with $10 \%$ trichloroacetic acid (final concentration). The samples were treated with an equal volume of $0.2 \% \mathrm{DNPH}$ in $2 \mathrm{M} \mathrm{HCl}$. To the Blank portions $2 \mathrm{M}$ $\mathrm{HCl}$ alone was added. The samples were incubated at room temperature in the dark for $1 \mathrm{~h}$, vortexing every $10 \mathrm{~min}$, after that they were centrifuged for $15-20 \mathrm{~min}$ at $3000 \mathrm{~g}$. The sediments were subsequently washed 3 times with ethanol-ethyl acetate ( $1: 1$, by vol.). The pellets were carefully drained and dissolved in $3 \mathrm{ml}$ of $8 \mathrm{M}$ carbamide, and then the samples were incubated for $5 \mathrm{~min}$ at $100{ }^{\circ} \mathrm{C}$. Insoluble debris was removed by centrifugation at $6000 \mathrm{~g}$ at $4{ }^{\circ} \mathrm{C}$. The reactive carbonyl content was calculated from its peak absorption of $365 \mathrm{~nm}$ using a molar absorption coefficient $21.0 \mathrm{mM}^{-1} \mathrm{~cm}^{-1}$. The concentration of total protein was measured by Bradford method [14].

Cholesterol and fatty acid profile determination. Total lipids of the liver were extracted and purified using the Bligh and Dyer methods [15]. Lipid 


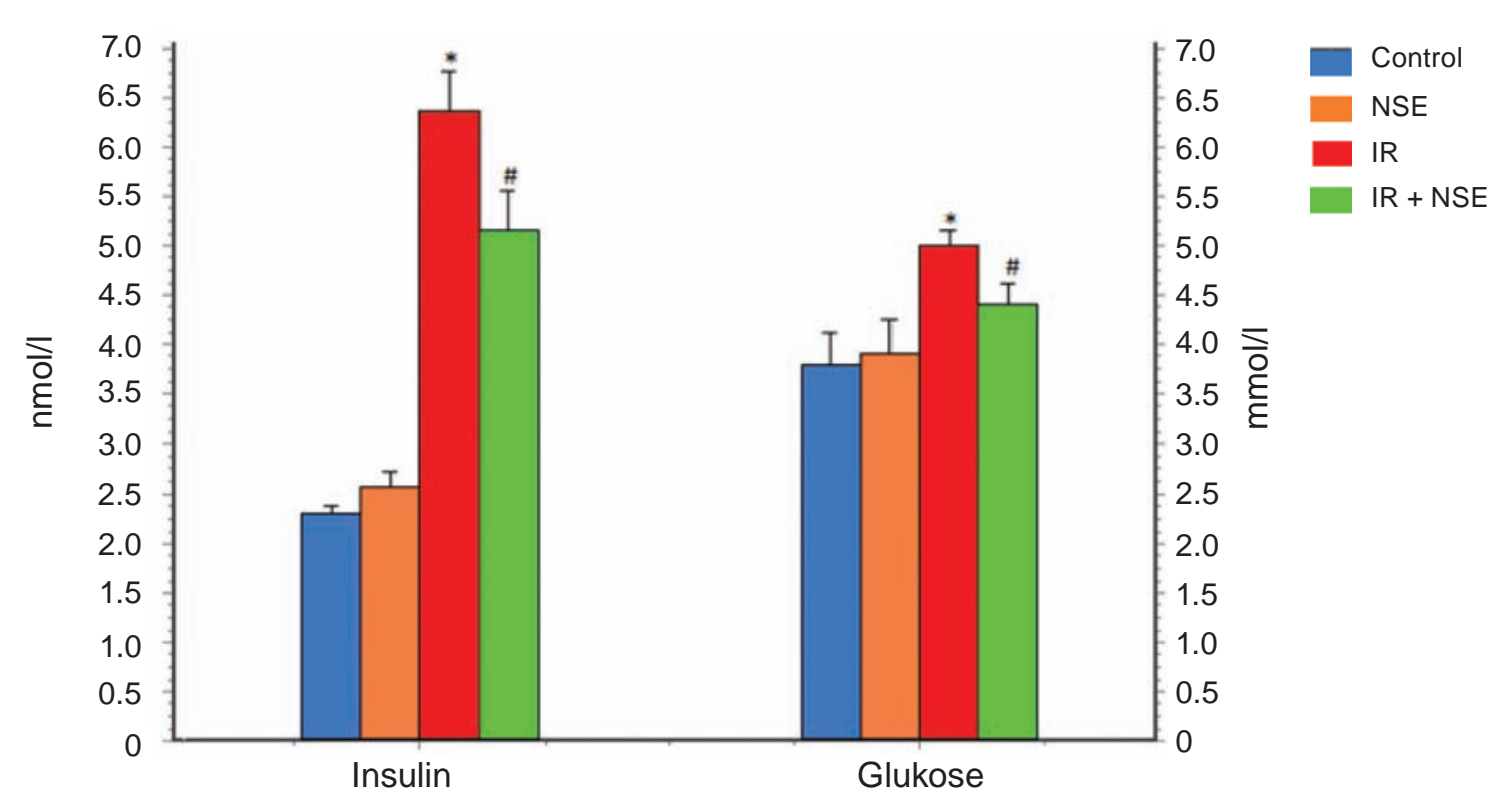

Fig. 1. Insulin content ( $\mathrm{nmol} / \mathrm{l})$ and glucose level ( $\mathrm{mmol} / \mathrm{l})$ in plasma in control and HFD rats. Values represented mean \pm SEM. Values in "Control" $(n=6)$, "NSE" $(n=6)$, "IR" $(n=9)$, “IR+NSE" $(n=10)$ were comparable. ${ }^{*} P<0.05$, compared to the rats of "Control" group; ${ }^{*} P<0.05$, compared to the "IR" group

fractions were separated by thin-layer chromatography using a solvent system of hexane/diethyl ether/ acetic acid (85:15:1, by vol.) cholesterol and stearic acid as standards. Fatty acid methyl esters were prepared by the modified method of Correau and Dubaco [16] and analyzed by gas-liquid chromatography. A Carlo Erba HRGC 5300 gas chromatograph (Italy) with flame ionization detector equipped with a glass packed column (length $-3.5 \mathrm{~m}$, internal diameter $3 \mathrm{~mm}$ ), completed with $10 \%$ SP-2300 phase (Silar 5CP) on "Chromosorb W/HP" was used to separate fatty acid methyl esters (FAMEs). The temperature was programmed from 140 to $250{ }^{\circ} \mathrm{C}$ at $2{ }^{\circ} \mathrm{C} / \mathrm{min}$ with a final hold. The FAMEs were identified by comparison of their retention times with those of individual purified standards (Sigma, USA; Serva, Germany). The level of individual fatty acids was quantified as a percentage of the total content.

The cholesterol fraction was taken and eluted by $3 \mathrm{ml}$ of diethyl ether. After evaporation of the solvent, the dry residue was assayed by gas-liquid chromatography on a glass column $(0.5 \mathrm{~m})$ packed with 1.5\% OV-1 on 80-100 mesh "Chimalite", and the instrument was operated at $250{ }^{\circ} \mathrm{C}$. The concentration of cholesterol was calculated in each sample by difference between obtained peak areas of the sample and the purified cholesterol standard.

Estimated $\Delta 9$-, $\Delta 6-, \Delta 5$-desaturase activities. The fatty acid desaturase (D) activities were esti- mated, using product-to-precursor indexes: $\Delta 9-\mathrm{D}$ as oleinic/stearic acids, $\Delta 6-\mathrm{D}$ as linolenic/linoleic acids, $\Delta 5$-D as arachidonic/linolenic, arachidonic/eicosatrienoic acids ratio [17].

Statistical analysis. The data, presented as mean values \pm standard errors of the means (SEM), were compared using the Student's unpaired $t$-test. The differences were considered significant at $P<0.05$.

\section{Results and Discussion}

The cholesterol determination showed significant increase in free liver cholesterol content (Fig. 2) from rats with alimentary obesity-induced IR compared with control group, whereas the cholesterol esters level was substantially reduced. The correlation between the increased liver free cholesterol level and the development of steatohepatitis was demonstrated earlier by Van Rooyen et al. in obese and mice with IR (HF-fed Foz/foz and wild type (WT)). Furthermore, high plasma insulin circulation can lead to prolonged, intense nonphysiological expression of the hepatic free cholesterol uptake transporter, lowdensity lipoprotein receptor and down-regulated cholesterol biotransformation in the liver [18]. The decreased level of cholesterol esters content may be associated with deficiency of lecithin:cholesterol acyl transferase (LCAT), a key enzyme that catalyzes the free cholesterol esterification. Taking into account 
that in our experiment, we did not overload rats with dietary cholesterol, the high accumulation of free cholesterol content and low level of esterified cholesterol may be associated with impaired mechanisms of its turnover. The NSE administration contributed to a decrease in free cholesterol content, simultaneously increasing cholesterol esters level in the liver of the rats with IR (Fig. 2) that showed the induction of esterification processes. As it was written earlier LCAT is the main enzyme, which catalyzes esterification of free cholesterol, thus we suggested the possibility of its up-regulation under NSE action. The LCAT plays a critical role in high-density lipoprotein (HDL) metabolism, markedly increasing HDL cholesterol content and lowering proatherogenic apoB-containing lipoproteins level [19].Thus, we suggest that compensatory effect of NSE on cholesterol ratio could be one of the possible protective mechanisms on liver tissue under HFD-induced IR.

The investigation of free fatty acid (FA) content in the liver of rats with obesity-induced IR demonstrated no differences in the total saturated and unsaturated fatty acid (accordingly SAFA and USFA) contents. However, the assay of the USFA composition in the liver of rats with IR (Fig. 3) showed a statistically significant increase in monounsaturated fatty acid (MUFA) level over that in the control group. This change was due to considerable increase in 18:1w9 level (Table 1) that may be associated with the increase in $\Delta 9$-desaturase estimated activity (Table 2). It is widely known that stearoyl-CoA-desaturase-1 (SCD-1) plays an important role in mediating the development of obesity and insulin resistance. In several studies it was found that a decrease in liver SCD-1 activity resulted on the one hand in the enhancing of protein kinase B phosphorylation, decrease in the expression of glucose-6-phosphatase, phosphoenolpyruvate carboxykinase [20]. On the other hand SCD-1 deficiency related to activation of lipid oxidation in addition to reduced triglyceride synthesis and storage [21]. Thus, down-regulation of SCD-1 can prevent the progression of adiposity and diet-induced hepatic insulin resistance in rats and mice. Recent studies have shown the positive effect of oral NSE administration on down-regulation of hepatic SCD-1 expression (male balb/c mice) [22]. The NSE administration to group of rats with IR resulted in a tendency to reduce hepatic $\Delta 9$-desaturase estimated activity (Table 2) and a statistically significant decrease in 18:1w9 level under NSE action (Table 1). The decrease in 18:1w9 content contributed to the reduction of general hepatic MUFA level from “IR+NSE” group compared with "IR" (Fig. 3).

In our study, we have found no considerable change in the dienoic fatty acid (DUFA) content in all experimental groups. However, the total con-

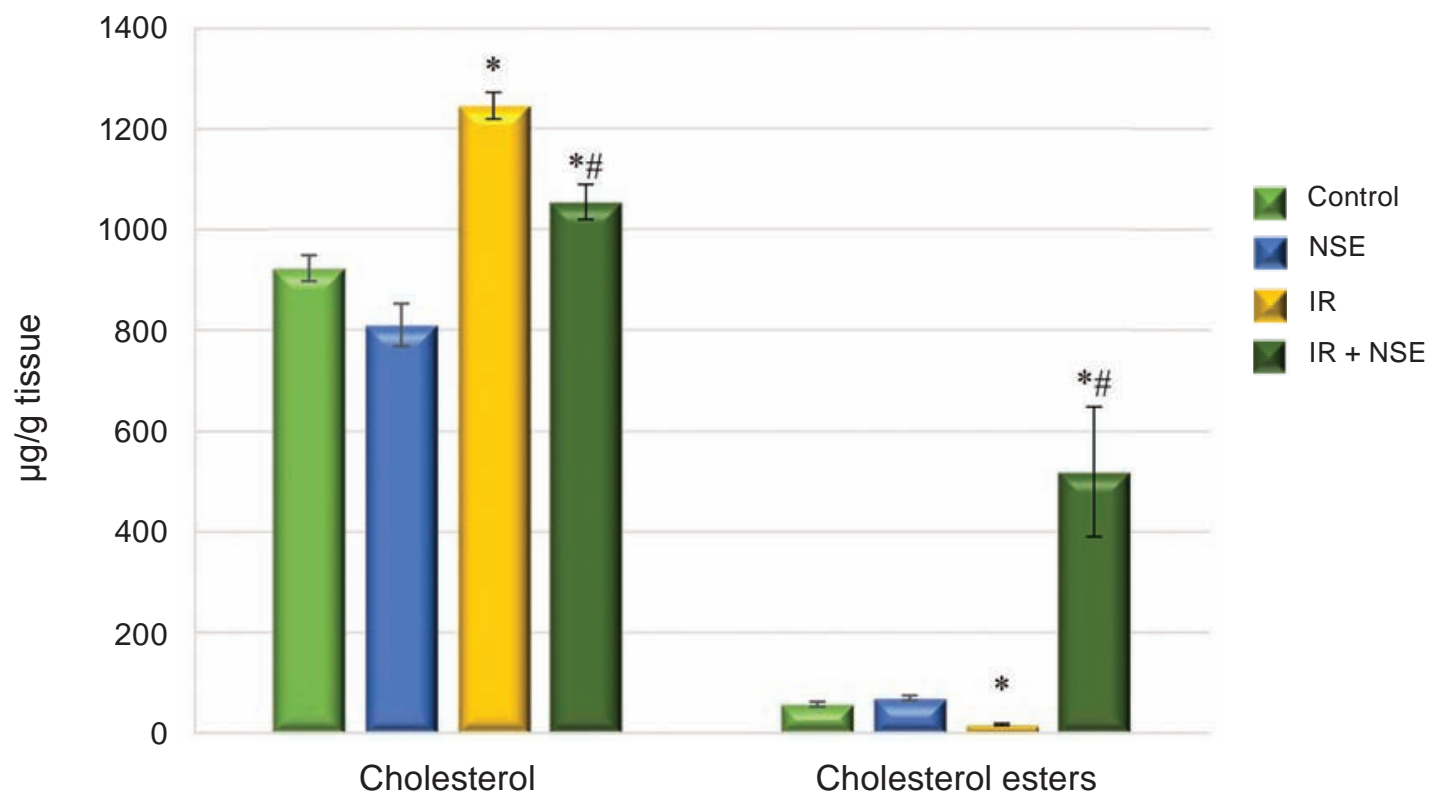

Fig. 2. Liver cholesterol and cholesterol esters content ( $\mu \mathrm{g} / \mathrm{g}$ tissue) in control and HFD rats. Values represented mean \pm SEM. Values in "Control» $(n=6)$, "NSE” $(n=6)$, "IR" $(n=9)$, “IR+NSE” $(n=10)$ were comparable. ${ }^{*} P<0.05$, compared to the rats of "Control" group; $P<0.05$, compared to the "IR" group; ${ }^{\circledR} P<0.05$, compared to the "NSE" group 
tent of polyunsaturated fatty acids (PUFA) in rats with IR was reduced, primarily 20:4w6 (Table 1) with a simultaneous decrease in estimated activity of $\Delta 5$-desaturase (Table 2). This was possibly due to $20: 4 w 6$ redistribution of the content between lipid fractions in the lipid imbalance case. Namely, in our previous study we showed the enhanced content of PUFA (20:4w6) in liver phospholipids from rats with IR that suggested involvement of PUFA in de novo phospholipid synthesis [23]. Earlier in clinical studies it was shown that free 20:4w6 was decreased significantly in patients with liver disease [24]. Low levels of 20:4w6 can, therefore, be associated with extensive liver impairment. In addition, recent data showed the depletion of long PUFA in fatty livers that inversely related to hepatic SCD-1 activity index and liver fat content [25]. This was consistent with the ability of PUFA to suppress expression of sterol regulatory element - binding protein (SREBP1c), SCD-1 and activate genes involved in hepatic fatty acid oxidation.

The effect of NSE on the increase in 20:4w6 content could be the consequence of its compensatory influence on lipid imbalance. Earlier we have shown that NSE administration to rats with IR decreased the 20:4w6 acid level in phospholipid composition over "IR" group [23]. Thus, the increased content of free 20:4w6 acid in the liver was due to its redistribution between lipid fractions under NSE action, normalizing the PUFA ratio. Another pathway of NSE action is thought to down-regulate the SCD-1 estimated activity that is to highly correlate with free PUFA content.

It is widely known that alongside with intracellular lipid imbalance, obesity-induced high FFA influx leads to increased generation of ROS, thus triggering the development of oxidative stress [26]. In this study, we have shown the depletion of PUFA that was associated with the liver oxidative stress [27]. Moreover, recently it was investigated that MUFAs were the targets for membrane lipid oxidation and their relevance in aldehyde generation [28]. Therefore, one of the main reasons of the high protein oxidation level (Fig. 4) in rats' liver was the increased content of MUFA under obesity-induced IR.

The presence of carbonyl groups in proteins may be considered as important markers of oxidative stress under the metabolic syndrome. Proteins are the principal target of ROS because they are present in high concentrations in biological systems and remove $50-75 \%$ of the generated ROS [29]. Oxidative damage of proteins is induced directly by ROS and indirectly by lipid peroxides that are initiated by oxidation of unsaturated lipid chains. It is interesting

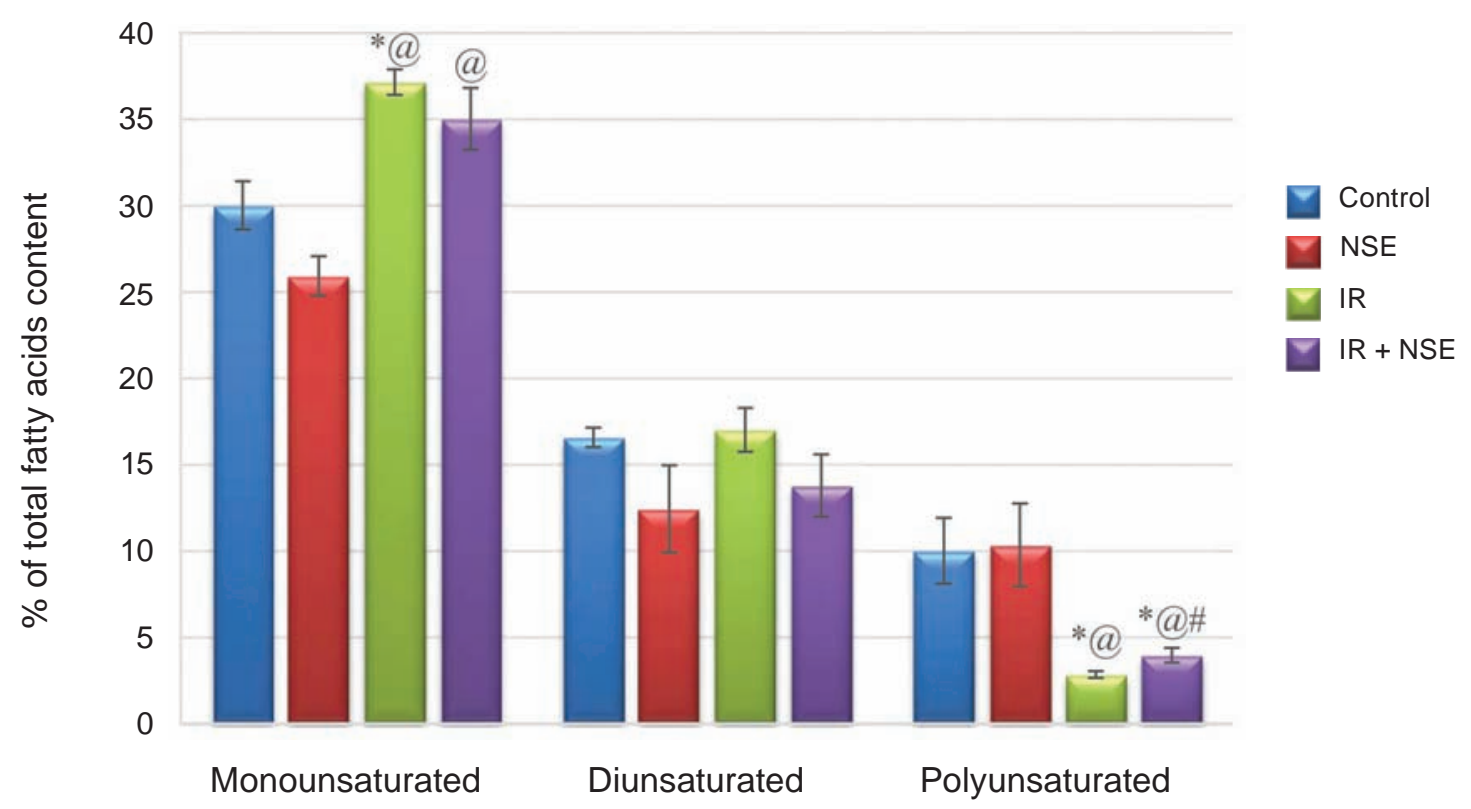

Fig. 3. Liver free unsaturated fatty acid content (\% of total fatty acid level) in control and HFD rats. Values represented mean \pm SEM. Values in "Control” $(n=6)$, "NSE" $(n=6)$, “IR" $(n=9)$, “IR+NSE” $(n=10)$ were comparable. ${ }^{*} P<0.05$, compared to the rats of "Control" group; $P<0.05$, compared to the "IR" group; ${ }^{\circledR} P<0.05$, compared to the “NSE” group 
Ta b le 1. Free fatty acid composition (\% of total fatty acid level) in the rat liver

\begin{tabular}{|c|c|c|c|c|}
\hline \multirow{2}{*}{ Fatty acid } & \multicolumn{4}{|c|}{ Experimental groups } \\
\hline & Control & NSE & IR & IR+NSE \\
\hline 10:0 & $0.162 \pm 0.038$ & $0.190 \pm 0.035$ & $0.056 \pm 0.007 *, @$ & $0.019 \pm 0.003^{*, @, \#}$ \\
\hline 11:0 & $0.077 \pm 0.018$ & $0.109 \pm 0.024$ & $0.045 \pm 0.017$ & $0.015 \pm 0.006^{*, @ ~}$ \\
\hline 12:0 & $0.154 \pm 0.035$ & $0.197 \pm 0.032$ & $0.059 \pm 0.009 * @$ & $0.026 \pm 0.008^{*, @, \#}$ \\
\hline 12:1 & $0.170 \pm 0.038$ & $0.247 \pm 0.052$ & $0.075 \pm 0.011^{* @ @ ~}$ & $0.091 \pm 0.06$ \\
\hline 13:0 & $0.258 \pm 0.062$ & $0.246 \pm 0.065$ & $0.113 \pm 0.034$ & $0.038 \pm 0.005^{*, @, \# ~}$ \\
\hline 14:1w5 & $0.270 \pm 0.066$ & $0.115 \pm 0.001$ & $0.059 \pm 0.018^{*}$ & $0.084 \pm 0.025^{*}$ \\
\hline 16:0 & $30.994 \pm 1.918$ & $28.510 \pm 3.759$ & $30.255 \pm 1.319$ & $29.686 \pm 1.312$ \\
\hline 16:1w9 & $1.854 \pm 0.383$ & $0.883 \pm 0.139 *$ & $1.318 \pm 0.100^{@}$ & $1.363 \pm 0.266$ \\
\hline $16: 2$ & $0.104 \pm 0.014$ & $0.125 \pm 0.013$ & $0.077 \pm 0.012^{@}$ & $0.097 \pm 0.014$ \\
\hline 17:0 & $0.440 \pm 0.049$ & $0.600 \pm 0.074$ & $0.559 \pm 0.035$ & $0.636 \pm 0.074^{*}$ \\
\hline 17:1w9 & $0.843 \pm 0.417$ & $0.741 \pm 0.14$ & $0.253 \pm 0.021^{@}$ & $0.367 \pm 0.052^{@}$ \\
\hline 18:0 & $9.055 \pm 2.26$ & $10.914 \pm 1.174$ & $9.138 \pm 0.621$ & $9.317 \pm 1.353$ \\
\hline 18:1w9 & $23.712 \pm 0.912$ & $21.288 \pm 2.274$ & $34.967 \pm 0.876 *$ @ & $29.962 \pm 1.302 *, @, \#$ \\
\hline $18: 2 w 6$ & $16.248 \pm 0.696$ & $10.402 \pm 2.086^{*}$ & $16.004 \pm 1.399 @$ & $15.411 \pm 1.747$ \\
\hline 18:3w6 & $0.116 \pm 0.014$ & $0.093 \pm 0.018$ & $0.269 \pm 0.054 * @$ & $0.191 \pm 0.05$ \\
\hline 20:0 & $0.286 \pm 0.049$ & $0.357 \pm 0.018$ & $0.150 \pm 0.015^{*, @ ~}$ & $0.262 \pm 0.026^{@, \#}$ \\
\hline 20:1w11 & $0.921 \pm 0.066$ & $0.573 \pm 0.12^{*}$ & $1.493 \pm 0.267 @$ & $1.211 \pm 0.145^{@}$ \\
\hline 20:4w6 & $8.484 \pm 1.584$ & $7.709 \pm 0.077$ & $1.882 \pm 0.078^{* @}$ & $3.219 \pm 0.477^{*}$.@,\# \\
\hline 21:0 & $0.484 \pm 0.207$ & $0.172 \pm 0.024$ & $0.464 \pm 0.118^{@}$ & $0.402 \pm 0.097 @$ \\
\hline 22:0 & $1.024 \pm 0.382$ & $0.756 \pm 0.008$ & $0.143 \pm 0.039 * @$ & $0.186 \pm 0.022 @$ \\
\hline 22:2w6 & $0.131 \pm 0.001$ & $0.183 \pm 0.002 *$ & $0.109 \pm 0.019 @$ & $0.132 \pm 0.03$ \\
\hline $22: 3$ & $0.261 \pm 0.024$ & $0.230 \pm 0.037$ & $0.266 \pm 0.063$ & $0.222 \pm 0.074$ \\
\hline $\mathrm{C} 24: 0$ & $0.305 \pm 0.096$ & $0.451 \pm 0.104$ & $0.169 \pm 0.028^{@}$ & $0.075 \pm 0.013^{* @, \#}$ \\
\hline Total SAFA & $42.912 \pm 1.281$ & $40.935 \pm 2.046$ & $43.406 \pm 0.838$ & $40.540 \pm 1.101$ \\
\hline Total USFA & $54.642 \pm 0.82$ & $58.027 \pm 1.911$ & $56.323 \pm 0.823$ & $58.986 \pm 1.13^{*}$ \\
\hline SAFA/USFA & $0.79 \pm 0.042$ & $0.811 \pm 0.109$ & $0.759 \pm 0.029$ & $0.846 \pm 0.111$ \\
\hline
\end{tabular}

Values represented mean \pm SEM. * $P<0.05$ compared to the rats of "Control" group; ${ }^{P} P<0.05$ compared to the "IR" group; ${ }^{\circledR} P<0.05$ compared to the “NSE” group

to submit that irreversible protein carbonylation initiates a down-regulation of key mitochondrialencoded proteins and transcription factors regulating mitochondrial biogenesis, thus leading to the development of insulin resistance [30]. Previously, in mice muscles an elevated level of TBA-reactive products and an increase of trans-4-hydroxy-2-nonenal (4-NHE)-modified IRS-1 was observed [31]. These changes of protein structure may lead to the decrease in tyrosin phosphorylation, PI3K activation, thus triggering the impairment of insulin signaling transduction.
The NSE administration caused the statistically significant reduction in the level of oxidative modification products of hepatic protein in rats with IR (Fig. 4). This may be the confirmation of insulin signaling improvement in the liver and, therefore, normalization of glucose tolerance and insulin sensitivity in rats under HFD-induced IR. The effect of NSE on protein carbonylation may be associated with its anti-inflammatory action, which was shown in our previous study by restoring pro-/anti-oxidative balance in the liver of rats with IR [10]. 
Ta b le 2. Hepatic estimated $\Delta 9-, \Delta 6-, \Delta 5$-desaturase activities of rats

\begin{tabular}{|c|c|c|c|c|}
\hline Free fatty acids & Control & NSE & IR & IR+NSE \\
\hline $\begin{array}{l}\Delta 6 \text {-desaturase } \\
\text { (18:3/18:2 ratio) }\end{array}$ & $0.007 \pm 0.001$ & $0.008 \pm 0.002$ & $0.012 \pm 0.002^{*}$ & $0.009 \pm 0.002$ \\
\hline $\begin{array}{l}\Delta 5 \text {-desaturase } \\
\text { (18:3/20:4 ratio) }\end{array}$ & $62.552 \pm 19.979$ & $101.792 \pm 1.018$ & $16.272 \pm 4.369 * @$ & $46.389 \pm 31.739$ \\
\hline $\begin{array}{l}\Delta 5 \text {-desaturase } \\
\text { (20:3/20:4 ratio) }\end{array}$ & $58.895 \pm 0.589$ & $216.514 \pm 2.165 *$ & $21.227 \pm 6.57 * @$ & $26.621 \pm 9.173^{* @}$ \\
\hline $\begin{array}{l}\Delta 9 \text {-desaturase } \\
\text { (18:1/18:0 ratio) }\end{array}$ & $2.892 \pm 0.412$ & $2.156 \pm 0.432$ & $3.761 \pm 0.411^{@}$ & $2.692 \pm 0.575$ \\
\hline
\end{tabular}

Therefore, our results indicated that NSE administration to the rats with obesity-induced IR contributed to the decrease in free cholesterol content and significant increase in cholesterol esters level. Under NSE action, the 20:4 acid level was increased and 18:1 acid level was decreased that may be associated with the influence of NSE on the desaturases activity. A significant reduction in protein carbonylation was observed as a result of compensatory effect of NSE on the lipid imbalance. Thus, a decrease of NSE effect on protein damage in the rat liver under obesity-induced IR may lead to the improvement of transmembrane protein function.

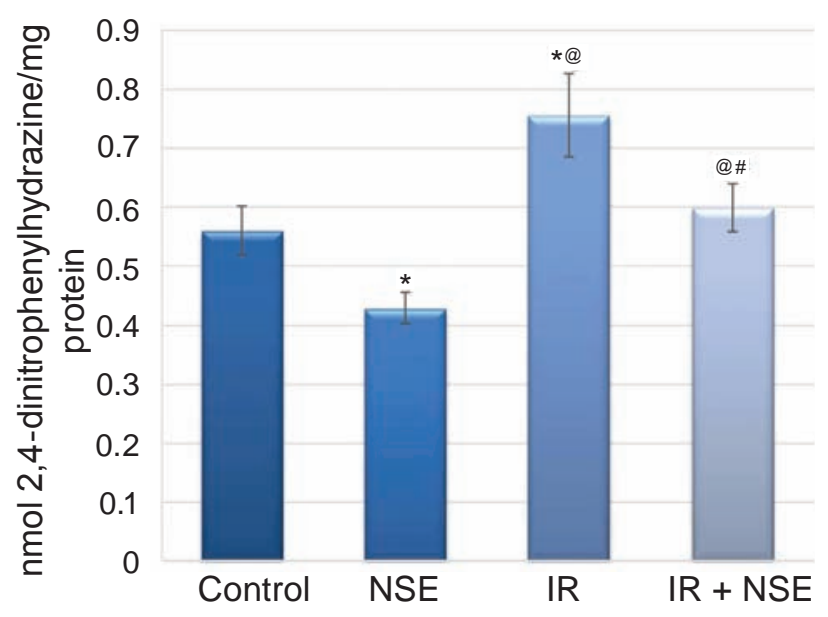

Fig. 4. Hepatic carbonylated proteins level (nmol 2,4-dinitrophenylhydrazine/mg protein) in control and HFD rats. Values represented mean \pm SEM. Values in "Control" $(n=6)$, "NSE" $(n=6)$, "IR" $(n=9)$, "IR+NSE" $(n=10)$ were comparable. $* P<0.05$, compared to the rats of "Control" group; ${ }^{\#} P<0.05$, compared to the "IR" group; ${ }^{\circledR} P<0.05$, compared to the "NSE" group

\section{ВПЛИВ N-СТЕАРОЇЛЕТАНОЛАМІНУ \\ НА ВМІСТ ХОЛЕСТЕРОЛУ, КАРБОНІЛЬОВАНИХ \\ ПРОТЕЇНІВ ТА СКЛАД ЖИРНИХ \\ КИСЛОТ У ПЕЧІНЦІ ЩУРІВ 3 \\ ІНСУЛІНОРЕЗИСТЕНТНІСТЮ, СПРИЧИНЕНОЮ АЛІМЕНТАРНИМ ОЖИРІННЯМ}

О. В. Онопченко, Г. В. Косякова,

О. Ф. Мегедь, В. М. Клімашевський, Н. М. Гула

Інститут біохімії ім. О. В. Палладіна НАН України, Київ; e-mail: onop.89.av@mail.ru

В роботі було досліджено вплив $\mathrm{N}$-стеароїлетаноламіну на склад вільних жирних кислот, вміст холестеролу та рівень карбонільованих протеїнів у печінці щурів з експериментальною інсулінорезистентністю (IP). Розвиток IP спричинювали шляхом довготривалого жирового навантаження (вміст ліпідів $58 \%$ від загального раціону) в комбінації з одноразовою ін'єкцією стрептозотоцину (15 мг/ кг маси тіла). Результати ліпідного аналізу показали зростання вмісту вільного та істотне зниження естерифікованого холестеролу в печінці щурів за ожиріння. Виявлено зниження рівня поліненасичених жирних кислот, значне збільшення мононенасичених жирних кислот. Також показано зростання вмісту протеїнових карбонілів внаслідок дисбалансу ліпідного складу печінки в умовах аліментарного ожиріння. Введення NSE (50 мг/кг маси тіла) протягом двох тижнів сприяло зниженню вмісту вільного холестеролу, зростанню його естерифікованої 
фракції та зменшенню вмісту олеїнової кислоти в печінці щурів 3 IP. Виявлено зниження вмісту продуктів окисної модифікації протеїнів у печінці щурів за дії NSE, що може мати позитивний вплив на функціональну активність трансмембранних протеїнів за IP, індукованої ожирінням.

К л ю ч о в і с л о в а: N-стеароїлетаноламін, холестерол, склад вільних жирних кислот, карбонілювання протеїнів, печінка, ожиріння, експериментальна інсулінорезистентність.

\section{ВЛИЯНИЕ \\ N-СТЕАРОИЛЭТАНОЛАМИНА \\ НА СОДЕРЖАНИЕ ХОЛЕСТЕРОЛА, КАРБОНИЛИРОВАННЫХ ПРОТЕИНОВ И СОСТАВ ЖИРНЫХ КИСЛОТ В ПЕЧЕНИ КРЫС С ИНСУЛИНОРЕЗИСТЕНТНОСТЬЮ, ВЫЗВАННОЙ АЛИМЕНТАРНЫМ ОЖИРЕНИЕМ}

\author{
А. В. Онопченко, Г. В. Косякова, \\ Е. Ф. Мегедь, В. М. Климашевский, \\ Н. М. Гулая
}

Институт биохимии им. А. В. Палладина НАН Украины, Киев; e-mail: onop.89.av@mail.ru

В работе исследовано влияние $\mathrm{N}$-стеароилэтаноламина на состав свободных жирных кислот, содержание холестерина и уровень карбонилированных протеинов в печени крыс с экспериментальной инсулинорезистентностью (ИР). ИР вызывали у крыс путем длительной жировой нагрузки (содержание липидов $58 \%$ от рациона) в комбинации с однократной инъекцией стрептозотоцина (15 мг/кг массы тела). Результаты липидного анализа показали увеличение уровня свободного холестерола и значительное снижение этерифицированного холестерола в печени крыс с ожирением. Обнаружено снижение уровня полиненасыщенных и увеличение содержания мононенасыщенных жирных кислот. Также показано увеличение количества протеиновых карбонилов в печени крыс как следствие липидного дисбаланса в условиях развития алиментарного ожирения. Введение N-стеароилэтаноламина (50 мг/кг массы тела в течении двух недель) способствовало снижению содержания свободного холестерола, увеличению его этерифицированной фракции и снижению уровня олеиновой кислоты в печени крыс с ИР. Показано снижение содержания продуктов окислительной модификации протеинов в печени крыс при действии NSE, что может оказывать положительное влияние на функциональную активность трансмембранных протеинов при ИР, индуцированной ожирением.

К лючевы е с лов а: N-стеароилэтаноламин, холестерол, состав свободных жирных кислот, карбонилирование протеинов, печень, ожирение, экспериментальная инсулинорезистентность.

\section{References}

1. Dandona P., Ghanim H., Chaudhuri A., Dhindsa S., Kim S. S. Macronutrient intake induces oxidative and inflammatory stress: Potential relevance to atherosclerosis and insulin resistance. Exp. Mol. Med. 2010;42(4):245-253.

2. Mlinar B., Marc J. New insights into adipose tissue dysfunction in insulin resistance. Clin. Chem. Lab. Med. 2011;49(12):1925-1935.

3. Yuzefovych L. V., Musiyenko S. I., Wilson G. L., Rachek L. I. Mitochondrial DNA damage and dysfunction, and oxidative stress are associated with endoplasmic reticulum stress, protein degradation and apoptosis in high fat dietinduced insulin resistance mice. PLoS One. 2013;8(1):e54059.

4. Turk Z. Glycotoxines, carbonyl stress and relevance to diabetes and its complications. Physiol. Res. 2010;59(2):147-156.

5. Curtis J. M., Hahn W. S., Long E. K., Burrill J. S., Arriaga E. A., Bernlohr D. A. Protein carbonylation and metabolic control systems.Trends Endocrinol. Metab. 2012;23(8):399-406.

6. Matteucci E., Biasci E., Giampietro O. Advanced oxidation protein products in plasma: stability during storage and correlation with other clinical characteristics. Acta Diabetol. 2001;38(4):187189.

7. Griffin M. E., Marcucci M. J., Cline G. W., Bell K., Barucci N., Lee D., Goodyear L. J., Kraegen E. W., White M. F., Shulman G. I. Free fatty acid-induced insulin resistance is associated with activation of protein kinase $\mathrm{C}$ theta and alterations in the insulin signaling cascade. Diabetes. 1999;48(6):1270-1274.

8. Kosiakova H. V., Hula N. M. The $\mathrm{N}$-stearoylethanolamine effect on the NO- 
synthase way of nitrogen oxide formation and phospholipid composition of erythrocyte membranes in rats with streptozotocine diabetes. Ukr. Biokhim. Zhurn. 2007;79(6):53-59. (In Ukrainian).

9. Goridko T. M., Gula N. M., Stogniy N. A., Meged O. F., Klimashevsky V. M., Shovkun S. A., Kindruk N. L., Berdyshev A. G. Influence of $\mathrm{N}$-stearoylethanolamine on the lipid peroxidation process and lipid composition of the rat liver under acute morphine intoxication. Ukr. Biokhim. Zhurn. 2007;79,(5):175-185. (In Ukrainian).

10. Onopchenko O. V., Kosiakova G. V., Goridko T. M., Berdyschev A. G., Meged O. F., Hula N. M. The effect of N-stearoylethanolamine on the activity of antioxidant enzymes, content of lipid peroxidation products and nitric oxide in the blood plasma blood and liver of rats with induced insulin-resistance. Ukr. Biokhim. Zhurn. 2013;85(5):88-96. (In Ukrainian).

11. Epps D. E., Natarajan V., Schmid P. C., Schmid H. O. Accumulation of N-acylethanolamine glycerophospholipids in infarcted myocardium. Biochim. Biophys. Acta. 1980;618(3):420-430.

12. Oliver C. N., Ahn B. W., Moerman E. J., Goldstein S., Stadtman E. R. Age-related changes in oxidized proteins. J. Biol. Chem. 1987;262(12):5488-5491.

13. Dubinina E. E., Burmistrov S. O., Khudov D. A., Porotov I. G. Oxidative modification of human blood serum proteins: a method for its estimation. Vopr. Med. Chim. 1995;41:24-26.

14. Bradford M. M. A rapid and sensitive method for the quantitation of microgram quantities of protein utilizing the principle of protein-dye binding. Anal. Biochem. 1976;72:248-254.

15. Bligh E. G., Dyer W. I. A rapid method of total lipid extraction and purification. Can. J. Biochem. Physiol. 1959;37:911-917.

16. Carreau I. D., Dubaco I. P. Adaptation of a macro-scale methods to the micro-scale for fatty acid methyl transcsterification of biological lipid extracts. J. Chromatogr. 1978;151:384-390.

17. McLauren Dorrance A., Graham D., Dominiczak A., Fraser R. Inhibition of nitric oxide synthesis increases erythrocyte membrane fluidity and unsaturated fatty acid content. Am. J. Hypertens. 2000;13(11):1194-202.
18. Van Rooyen D. M., Larter C. Z., Haigh W. G., Yeh M. M., Ioannou G., Kuver R., Lee S. P., Teoh N. C., Farrell G. C. Hepatic free cholesterol accumulates in obese, diabetic mice and causes nonalcoholic steatohepatitis. Gastroenterology. 2011;141(4):1393-403.

19. Kunnen S., Van Eck M. Lecithin:cholesterol acyltransferase: old friend or foe in atherosclerosis? J. Lipid. Res. 2012;53(9):17831799.

20. Ntambi J. M., Miyazaki M., Stoehr J. P., Lan H., Kendziorski C. M., Yandell B. S., Song Y., Cohen P., Friedman J. M., Attie A. D. Loss of stearoyl-CoA desaturase-1 function protects mice against adiposity. PNAS. 2002;99(17):1711482-11486.

21. Gutiérrez-Juárez R., Pocai A., Mulas C., Ono H., Bhanot S., Monia B. P., Rossetti L. Critical role of stearoyl-CoA desaturase-1 (SCD1) in the onset of diet-induced hepatic insulin resistance. J. Clin. Invest. 2006;116(6):1686-1695.

22. Terrazzino S., Berto F., Dalle Carbonare M., Fabris M., Guiotto A., Bernardini D., Leon A. Stearoylethanolamide exerts anorexic effects in mice via down-regulation of liver stearoylcoenzyme A desaturase-1 mRNA expression. FASEB J. 2004;18(13):1580-1582.

23. Onopchenko O. V., Kosiakova G. V., Goridko T. M., Klimashevsky V. M., Hula N. M. The effect of $\mathrm{N}$-stearoylethanolamine on liver phospholipid composition of rats with insulin resistance caused by alimentary obesity. Ukr. Biochem. J. 2014;86(1):101-110. (In Ukrainian).

24. Ólafur Gunnlaugsson M. D., Donald Berkowitz M. D. Individual Free Fatty Acids in Patients with liver disease. Am. J. Dig. Dis. 1977;22(11):1005-1009.

25. Kotronen A., Seppanen-Laakso T., Westerbacka J. Hepatic stearoyl-CoA desaturase (SCD)-1 activity and diacylglycerol but not ceramide concentrations are increased in the nonalcoholic human fatty liver. Diabetes. 2009;58(1):203-208.

26. Savini I., Catani M. V., Evangelista D., Gasperi V., Avigliano L. Obesity-associated oxidative stress: strategies finalized to improve redox state. Int. J. Mol. Sci. 2013;14(5):10497538.

27. Espinosa A., Valenzuela B. R., GonzálezMañán D. Prevention of liver steatosis through fish oil supplementation:correlation of oxidative 
stress with insulin resistance and liver fatty acid content. Arch. Latinoam. Nutr. 2013;63(1):29-36.

28. Pradenas G. A., Díaz-Vásquez W. A., PérezDonoso J. M., Vásquez C. C. Monounsaturated fatty acids are substrates for aldehyde generation in tellurite-exposed Escherichia coli. Biomed. Res. Int. 2013;2013:563756.

29. Hopps E., Caimi G. Protein oxidation in metabolic syndrome. Clin. Invest. Med. 2013;36:E1-E8.

30. Curtis J. M., Hahn W. S., Stone M. D., Inda J. J., Droullard D. J., Kuzmicic J. P., Donoghue M. A.,
Long E. K., Armien A. G., Lavandero S., Arriaga E., Griffin T. J., Bernlohr D. A. Protein carbonylation and adipocyte mitochondrial function. J. Biol. Chem. 2012;287(39):32967-80.

31. Aoi W., Naito Y., Tokuda H., Tanimura Y, OyaIto T., Yoshikawa T. Exercise-induced muscle damage impairs insulin signaling pathway associated with IRS-1 oxidative modification. Physiol. Res. 2012;61(1):81-88.

Received 11.02.2014 